American Journal of Biochemistry and Biotechnology 5 (1): 1-6, 2009

ISSN 1553-3468

(C) 2009 Science Publications

\title{
The Effect of Higher Sludge Recycling Rate on Anaerobic Treatment of Palm Oil Mill Effluent in a Semi-Commercial Closed Digester for Renewable Energy
}

\author{
${ }^{1,2}$ Alawi Sulaiman, ${ }^{3}$ Zainuri Busu, ${ }^{3}$ Meisam Tabatabaei, ${ }^{4}$ Shahrakbah Yacob, \\ ${ }^{3}$ Suraini Abd-Aziz, ${ }^{1,3}$ Mohd Ali Hassan and ${ }^{5}$ Yoshihito Shirai \\ ${ }^{1}$ Faculty of Engineering, University Putra Malaysia, 43400 UPM Serdang, Selangor, Malaysia \\ ${ }^{2}$ Faculty of Chemical Engineering, University Technology MARA, \\ 40450 Shah Alam, Selangor, Malaysia \\ ${ }^{3}$ Faculty of Biotechnology and Biomolecular Sciences, University Putra Malaysia, \\ 43400 UPM Serdang, Selangor, Malaysia \\ ${ }^{4}$ Applied Agricultural Resources Sdn. Bhd., $1 / 2 \mathrm{~km}$ off Jalan Sg Buloh-Subang, \\ 47000 Sg. Buloh, Selangor, Malaysia \\ ${ }^{5}$ Graduate School of Life Sciences and Systems Engineering, Kyushu Institute of Technology, \\ 2-4 Hibikino, Wakamatsu-ku, Kitakyushu, Fukuoka 808-0196, Japan
}

\begin{abstract}
Problem statement: A $500 \mathrm{~m}^{3}$ semi-commercial closed anaerobic digester was constructed for Palm Oil Mill Effluent (POME) treatment and methane gas capture for renewable energy. During the start-up operation period, the Volatile Fatty Acids (VFA) accumulation could not be controlled and caused instability on the system. Approach: A settling tank was installed and sludge was recycled as to provide a balanced microorganisms population for the treatment of POME and methane gas production. The effect of sludge recycling rate was studied by applying Organic Loading Rates (OLR) (between 1.0 and $10.0 \mathrm{kgCOD} \mathrm{m}^{-3} \mathrm{day}^{-1}$ ) at different sludge recycling rates $\left(6,12\right.$ and $18 \mathrm{~m}^{3} \mathrm{day}^{-1}$ ). Results: At sludge recycling rate of $18 \mathrm{~m}^{3} \mathrm{day}^{-1}$, the maximum OLR was $10.0 \mathrm{kgCOD} \mathrm{m}^{-3}$ day $^{-1}$ with biogas and methane productivity of 1.5 and $0.9 \mathrm{~m}^{3} \mathrm{~m}^{-3}$ day $^{-1}$, respectively. By increasing the sludge recycling rate the VFA concentration was controlled below its inhibitory limit $\left(1000 \mathrm{mg} \mathrm{L}^{-1}\right)$ and the COD removal efficiency recorded was above $95 \%$ which indicated good treatment performance for the digester. Two methanogens species (Methanosarcina sp. and Methanosaeta concilii) had been identified from sludge samples obtained from the digester and recycled stream. Conclusion: By increasing the sludge recycling rate upon higher application of OLR, the treatment process was kept stable with high COD removal efficiency. The biogas and methane productivity were initially improved but reduced once OLR and recycling rate were increased to $10.0 \mathrm{~kg} \mathrm{COD} \mathrm{m}^{3} \mathrm{day}^{-1}$ and $18 \mathrm{~m}^{3}$ day $^{-1}$ respectively.
\end{abstract}

Key words: Palm oil mill effluent, methane, biogas, clean development mechanism

\section{INTRODUCTION}

Globally there is a great concern for reducing the emission of Green Houses Gases (GHG) through Clean Development Mechanism (CDM) projects for renewable energy. In Malaysia one of the attractive projects for CDM and renewable energy is the methane gas capture from anaerobic treatment of Palm Oil Mill Effluent (POME) because it contains high amount of organic substances which are mainly lignocellulosic materials. In the world, POME contributes the largest effluent discharge compared to other oil extraction process $^{[1]}$. Unfortunately in Malaysia, the most popular treatment method for POME which is utilized by more than $85 \%$ of the mills is the open ponds system ${ }^{[2]}$. This is due to its low capital and operating costs. However with the implementation of CDM project under the Kyoto Protocol, open ponds treatment system is becoming less attractive because the valuable gas (methane) is wasted to the atmosphere and the system could not be certified for Carbon Emission Reduction (CER) trading.

Corresponding Author: Alawi Sulaiman, Faculty of Engineering, University Putra Malaysia, 43400 UPM Serdang, Selangor, Malaysia, Faculty of Chemical Engineering, University Technology MARA, 40450 Shah Alam, Selangor, Malaysia 
In an anaerobic digestion process, the organic materials are converted into biogas which mainly composed of methane and carbon dioxide by the action of a consortium of microorganisms through series of metabolic stages namely hydrolysis, acidogenesis, acetogenesis and methanogenesis ${ }^{[3-5]}$. By closing the digester in oppose to the conventional system, the methane gas could be captured and used for electricity generation. In addition, high Chemical Oxygen Demand (COD) removal efficiency could be achieved in shorter retention time. So far there were many reports on the anaerobic treatment of POME and methane generation, however none has been tested at a large pilot scale specifically for CDM study ${ }^{[6-10]}$. Therefore in 2005, a $500 \mathrm{~m}^{3}$ semi-commercial anaerobic digester was constructed and the digester has been in operation since then ${ }^{[1] .}$ The objective of this study is to investigate the digester performances on COD removal efficiency and methane gas productivity at different OLR and sludge recycling rates applied.

\section{MATERIALS AND METHODS}

Figure 1 shows the diagram of the digester system used previously by Yacob et al. ${ }^{[1]}$ except for the sludge settling tank which was installed for this study. The POME used was obtained daily from the mixing pond of the Serting Hilir Palm Oil Mill by using a pump. The POME was stored temporarily in the holding tank prior to feeding. The sludge from the treated effluent was collected in the settling tank and let to settle. The settled sludge was then returned to the digester at different recycling rates $\left(6,12\right.$ and $18 \mathrm{~m}^{3}$ day $\left.^{-1}\right)$. Minimal mixing was applied intermittently for every $6 \mathrm{~h}$ (for $30 \mathrm{~min}$ ) by using the mixing pump as to provide good contact between substrate and microorganisms. The COD, $\mathrm{pH}$, Volatile Fatty Acids (VFA), alkalinity, biogas mass flow and POME mass flow were measured by using the standard methods for the examination of water and wastewater (American Public Health Association $)^{[11]}$. The methane concentration was measured using a portable methane gas analyzer (XP-314A, Shin-Cosmos Electric Co. Ltd. Japan).

The analyzer was calibrated at the manufacturer's site in Japan. The probe MSMX860, complementary to the 16S rRNA of some methanogens including Methanosarcina spp., Methanococcoides spp., Methanolobus spp., Methanohalophilus spp. and Methanosaeta spp. was used to directly analyze the methanogenic population ${ }^{[12]}$. To determine the sludge bacteria, the 16S rRNA probe EUB338 for the bacteria domain was used ${ }^{[13]}$. Oligonucleotides and their fluorescent derivatives (5'-labelled with either FITC or rhodamine) were purchased from First Base (Malaysia) Sdn. Bhd. Cells were fixed and hybridized using the protocol reported by $\mathrm{Amman}^{[14]}$ with some modifications ${ }^{[15]}$. Fluorescence was observed using an epifluorescence microscope (BX50; Olympus, Tokyo, Japan) and photomicrographs were taken using a chilled 3-CCD color camera $(640 \times 483$ pixels, C5810; Hamamatsu Photonics, Shizuoka, Japan).

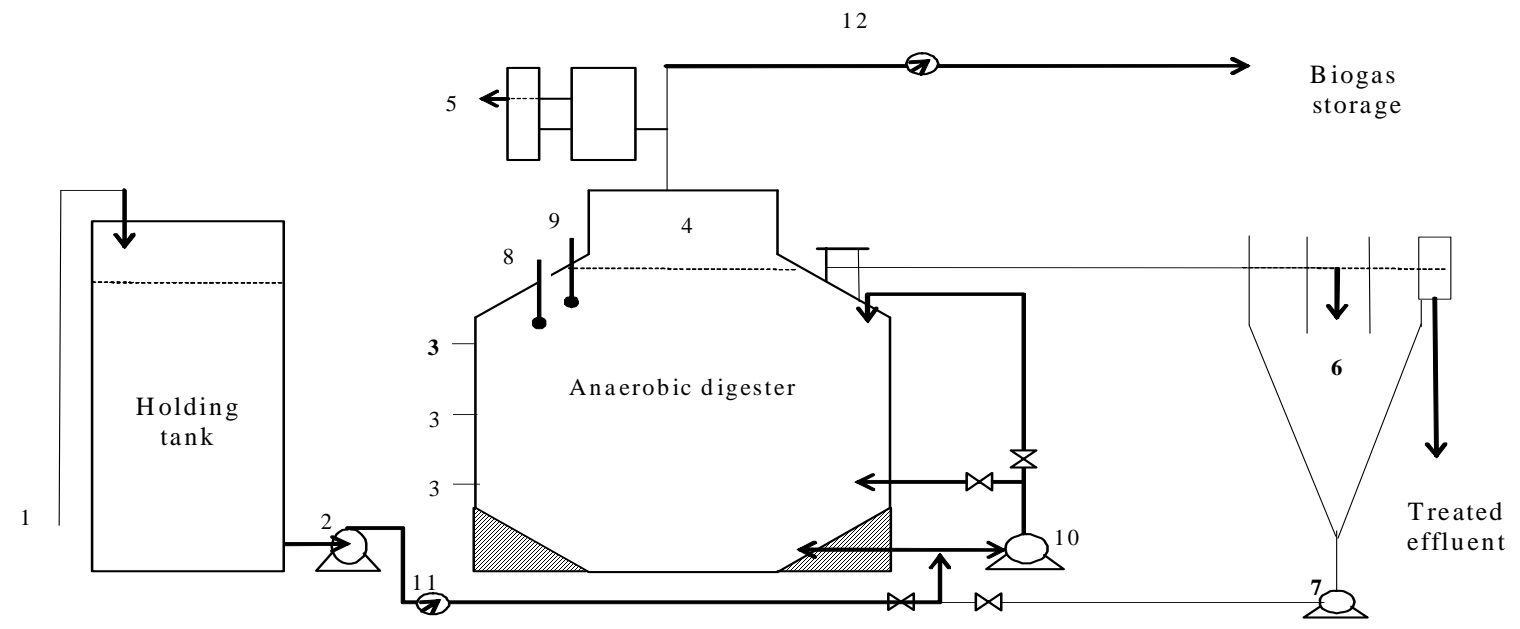

Fig. 1: Schematic diagram of the $500 \mathrm{~m}^{3}$ semi-commercial closed anaerobic digester; (1): Fresh POME inlet; (2): Feeding pump; (3): Sampling ports; (4): Gas collection chamber; (5): Biogas safety relief system; (6): Settling tank; (7): Sludge recycling pump; (8): pH probe; (9): Temperature probe; (10): Mixing pump; (11): POME mass flow meter; (12): Biogas mass flow meter 


\section{RESULTS}

Table 1 shows the sludge recycling rate applied, COD levels in the raw POME, raw POME feeding rate, Hydraulic Retention Time (HRT), Organic Loading Rate (OLR), digester's $\mathrm{pH}$ and COD removal efficiency recorded in this study. A total of 111 days of operation was sustained in this study at different COD concentration $\left(66,400-118,100 \mathrm{mg} \mathrm{L}^{-1}\right)$, OLR (1.0-10.0 $\mathrm{kgCOD} \mathrm{m}^{-3} \mathrm{day}^{-1}$ ) and sludge recycling rate (6.0-18.0 $\left.\mathrm{m}^{3} \mathrm{day}^{-1}\right)$. The variation of OLR applied resulted in different POME feeding rate and HRT applied as well. The last two columns show the digester's stability in terms of $\mathrm{pH}$ and $\mathrm{COD}$ removal efficiency achieved. The COD removal efficiency recorded the same performance for different OLR and sludge recycling rate applied which indicated lower recycling rate was sufficient for lower OLR application and higher recycling rate was required once OLR was increased in the system.
Figure 2 shows the VFA concentration in the digester, methane yield achieved and productivity of biogas and methane at different OLR and sludge recycling rate applied. The VFA level was initially low in the digester but increased once OLR was increased. By increasing the sludge recycling rate the VFA level was controlled below $1000 \mathrm{mg} \mathrm{L}^{-1}$ and OLR was able to be applied up to $10.0 \mathrm{kgCOD} \mathrm{m}^{-3} \mathrm{day}^{-1}$. Productivity of biogas and methane also increase with OLR but reduced towards the end of study. Initially the methane yield was high but slowly reduced once higher OLR and sludge recycling rate was applied.

The results of methanogens population analysis in the digester and the recycled sludge by using Fluorescent In Situ Hybridization (FISH) technique is shown in Fig. $3 \mathrm{~A}$ and $\mathrm{B}$ respectively. These diagrams confirm the presence of filamentous Methanosaeta concilii and the clover-leaved Methanosarcina sp. in both sludge samples.

Table 1: Feeding profiles, stability and COD removal performance of the digester

\begin{tabular}{|c|c|c|c|c|c|c|c|}
\hline \multirow[b]{2}{*}{$\begin{array}{l}\text { Operation } \\
\text { period days }\end{array}$} & \multirow{2}{*}{$\begin{array}{l}\text { Sludge } \\
\text { recycling } \\
\text { rate } \mathrm{m}^{3} \text { day }^{-1}\end{array}$} & \multicolumn{4}{|c|}{ Feeding profiles } & \multicolumn{2}{|c|}{ Digester stability and performance } \\
\hline & & $\begin{array}{l}\text { COD of raw } \\
\text { POME mg L }\end{array}$ & $\begin{array}{l}\text { Feeding rate } \\
\mathrm{m}^{3} \mathrm{day}^{-1}\end{array}$ & $\begin{array}{l}\text { Hydraulic retention } \\
\text { time days }\end{array}$ & $\begin{array}{l}\text { Organic loading } \\
\text { rate } \mathrm{kgCOD} \mathrm{m}^{-3} \mathrm{day}^{-1}\end{array}$ & $\mathrm{pH}$ & $\begin{array}{l}\text { COD removal } \\
\text { efficiency }(\%)\end{array}$ \\
\hline $1-9$ & 6.0 & 66,400 & 7.7 & 64.9 & 1.0 & 6.8 & 97.3 \\
\hline $10-28$ & 6.0 & 75,900 & 15.5 & 32.2 & 2.0 & 6.8 & 97.6 \\
\hline $29-38$ & 6.0 & 80,700 & 21.8 & 22.9 & 3.0 & 6.9 & 96.6 \\
\hline $39-58$ & 12.0 & 86,300 & 27.4 & 18.2 & 4.0 & 6.9 & 96.7 \\
\hline $59-78$ & 12.0 & 98,900 & 33.5 & 14.9 & 5.0 & 7.0 & 98.1 \\
\hline $79-84$ & 12.0 & 103,000 & 38.3 & 13.0 & 6.0 & 7.1 & 97.7 \\
\hline $85-95$ & 18.0 & 111,600 & 37.8 & 13.2 & 7.0 & 7.0 & 97.7 \\
\hline $96-105$ & 18.0 & 118,100 & 39.3 & 12.7 & 8.0 & 7.0 & 97.6 \\
\hline $106-111$ & 18.0 & 111,100 & 46.6 & 10.7 & 10.0 & 7.0 & 97.5 \\
\hline
\end{tabular}

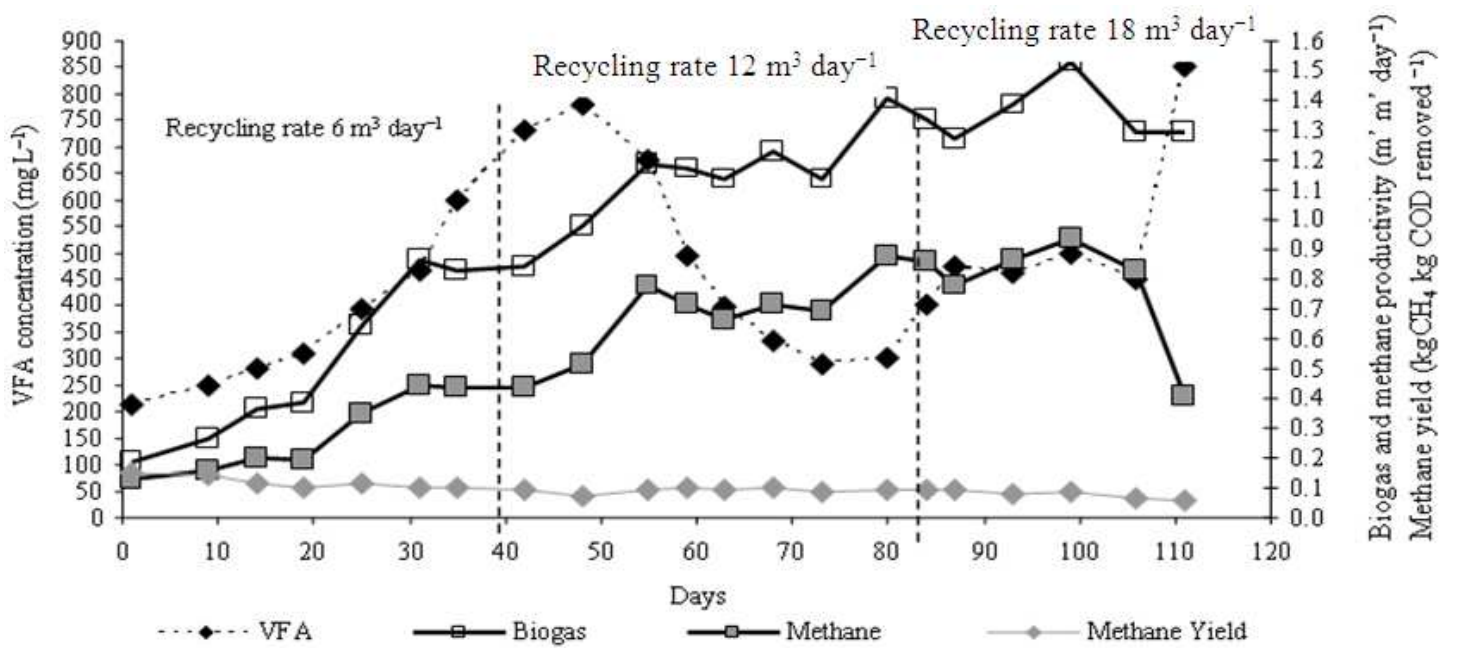

Fig. 2: Productivities of biogas and methane, methane yield and VFA concentration profiles 

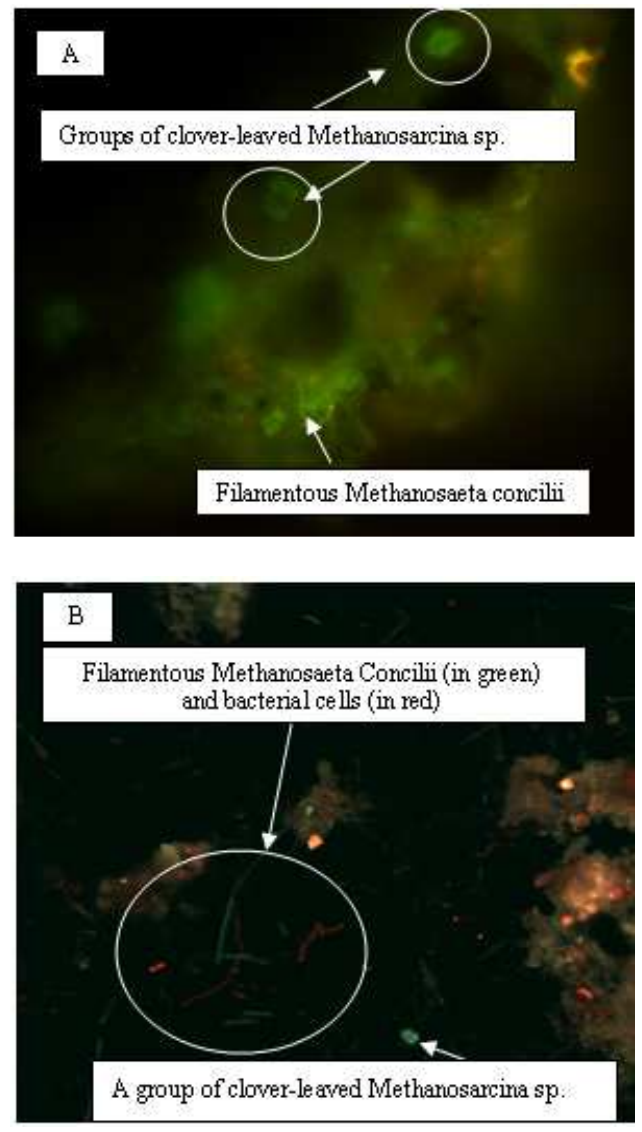

Fig. 3: Fluorescent In Situ Hybridization (FISH) picture for the samples taken from the digester (A): 1000X magnification and recycled sludge (B): 200X magnification showing the distribution of methanogens (Methanosaeta concilii and Methanosarcina sp.)

In the recycled sludge sample, the population of Methanosarcina sp. was lower but there is a considerable amount of Methanosaeta concilii observed.

\section{DISCUSSION}

COD removal efficiency and OLR applied: In many studies the COD removal efficiency recorded was high although high fluctuation of COD concentration were applied ${ }^{[6-10]}$. Similarly in this study, the COD concentrations fluctuated between 66,000 and $118,000 \mathrm{mg} \mathrm{L}^{-1}$ as shown in Table 1 . The anaerobic treatment system was stable which was due the suitable anaerobic treatment system design for POME. The actual organic level in POME varies daily and the ability of the system to run continuously is important as to ensure minimal down-time and increase biogas productivity once the project has been approved for CDM. From Table 1, the COD removal efficiency maintained removal efficiency of greater than $95 \%$ despite higher OLR applied to the system. This signify the importance of applying higher sludge recycling rate in order to maintain high COD removal once OLR was increased. During 111 days of continuous operation, the OLR was increased in step-wise (from 1.0-10.0 $\mathrm{kgCOD} \mathrm{m}^{-3} \mathrm{day}^{-1}$ ). This resulted in higher POME feeding rate and shorter Hydraulic Retention Time (HRT). In the previous study at OLR of between 5.0 and $6.0 \mathrm{kgCOD} \mathrm{m}^{-3}$ day $^{-1}$ the digester became unstable due to VFA accumulation inside the digester and the treatment could not be sustained ${ }^{[1]}$. However in this study higher OLR was achieved (up to $10.0 \mathrm{kgCODm}^{-3} \mathrm{day}^{-1}$ ) and the system remained stable (neutral $\mathrm{pH}$ with COD removal efficiency greater than $95 \%$ ) by increasing the sludge recycling rate from the settling tank at different rates. From days 1-40 the sludge recycling rate was fixed at $6 \mathrm{~m}^{3}$ day $^{-1}$ and increased to $12 \mathrm{~m}^{3} \mathrm{day}^{-1}$ (from days 39-78) and finally to $18 \mathrm{~m}^{3}$ day $^{-1}$ (from days 91-110) as shown in Table 1. During these different periods, the OLR were also increased steadily from 1.0-10.0 $\mathrm{kgCOD} \mathrm{m}^{-3}$ day $^{-1}$ with an increment of $1.0 \mathrm{kgCOD} \mathrm{m}^{-3} \mathrm{day}^{-1}$ except for the last increment.

Volatile Fatty Acids (VFA) accumulation: Figure 2 shows the VFA concentration in the digester, productivity of biogas and methane and methane yield achieved in this study. From this study at lower OLR applied (from 1.0- 4.0 $\mathrm{kgCOD} \mathrm{m}^{-3} \mathrm{day}^{-1}$ ), the measured VFA concentration inside the digester was low which indicates good VFA utilization by the methanogens. However after 40 days of operation, the VFA concentration was recorded higher (nearly $900 \mathrm{mg} \mathrm{L}^{-1}$ ). In order to avoid the process to turn acidic and inhibit the methanogenesis process, higher sludge recycling rate was applied at $12 \mathrm{~m}^{3}$ day $^{-1}$ by increasing the pump's timer. The VFA concentration in the digester reduced steadily with time as shown in Fig. 2. In earlier study the sludge recycling strategy was suggested in order to supplement alkalinity and maintain the system's $\mathrm{pH}^{[10]}$. By recycling the sludge, the active microorganisms could be returned to the digester and provide a balanced population of microorganisms that responsible for converting organics materials to VFA and methane gas. The system was stable until OLR of $6.0 \mathrm{kgCOD} \mathrm{m}^{-3}$ day $^{-1}$ where the VFA concentration in the digester showed an increasing trend. In order to avoid the process to turn acidic, the sludge recycling rate was increased to $18 \mathrm{~m}^{3} \mathrm{day}^{-1}$. As a result, the VFA concentration was maintained below $1000 \mathrm{mg} \mathrm{L}^{-1}$. 
Productivity of biogas and methane and methane yield: The productivity of biogas and methane and methane yield are shown in Fig. 2. The productivity shows the biogas volume at standard temperature and pressure measured in a day over the volume of reactor. In this study, the gas productivity increased with OLR applied where the maximum biogas and methane productivity were recorded at 1.5 and $0.9 \mathrm{~m}^{3} \mathrm{~m}^{-3} \mathrm{day}^{-1}$, respectively at OLR of $8.0 \mathrm{kgCOD} \mathrm{m}^{-3} \mathrm{day}^{-1}$. However, after 100 days of operation when OLR and sludge recycling rate were increased to $10.0 \mathrm{kgCOD} \mathrm{m}^{-3} \mathrm{day}^{-1}$ and $18 \mathrm{~m}^{3}$ day $^{-1}$ respectively, biogas and methane productivity reduced to 1.3 and $0.4 \mathrm{~m}^{3} \mathrm{~m}^{-3}$ day $^{-1}$, respectively. This reflects the occurrence of anaerobic inhibition in the system. Theoretically, higher biogas productivity should be achieved with higher OLR applied but this was not observed towards the end of the study which may be due to the organic washout. Towards the end, the sludge recycling rate was increased to $18 \mathrm{~m}^{3}$ day $^{-1}$ and some of the organics were washed out from the digester and could not be converted into biogas even though higher amount of microorganisms available. In addition, higher feeding volume was also introduced to the digester which may have resulted in shock loading to the microorganism as well and might have contributed to the reduced biogas generation $^{[1]}$. For the methane yield the trend was different where it was highest at lowest OLR applied and slowly reduced once it was increased as shown in Fig. 2. At lower OLR the methane yield was around $0.15 \mathrm{kgCH}_{4} \mathrm{kgCODremoved}^{-1}$ but reduced to $0.10 \mathrm{kgCH}_{4} \mathrm{kgCODremoved}^{-1}$ and finally to $0.06 \mathrm{kgCH}_{4} \quad \mathrm{kgCODremoved}^{-1}$ when OLR was increased to 5.0 and $10.0 \mathrm{kgCOD} \mathrm{m^{-3 }}$ day $^{-1}$, respectively. Although the sludge recycling rate were increased to 12.0 and $18.0 \mathrm{~m}^{3}$ day $^{-1}$ it was not sufficient to increase the methane yield performance.

Fluorescent In Situ Hybridization (FISH): The analysis of methanogens population in the digester and the recycled sludge by using the Fluorescent In Situ Hybridization (FISH) technique confirmed the presence of filamentous Methanosaeta concilii and the cloverleaved Methanosarcina sp. in both recycled and digester sludge samples as shown in Fig. 3. The population of Methanosarcina sp. was lower in the recycled sludge sample (Fig. 3B) as compared to the digester sludge sample (Fig. 3A). However there is a considerable amount of Methanosaeta concilii in the recycled sludge which highlights the importance of recycling the sludge to the digester to maintain high population of both important mesophilic acetolastic methanogens which responsible for methanogenesis process $^{[16]}$.

Methane emission reduction: Based on this study the methane emission reduction could be estimated by using the volumetric ratio of methane produced and POME utilized. From this study the calculated ratio is approximately 12.0. In 2007, the total volume of POME generated for a 54 tones $\mathrm{h}^{-1}$ Serting Hilir Palm Oil Mill was $192,372 \mathrm{~m}^{3}$. This accounted for methane emission reduction of 2,308,464 $\mathrm{m}^{3}$ of methane. Considering that there are hundreds of palm oil mills in Malaysia and CER could be traded at the rate of USD10/ton of $\mathrm{CO}_{2}$ equivalent, there is a huge potential for CDM business in Malaysia.

\section{CONCLUSION}

This study demonstrated the feasibility of methane gas capturing project for $\mathrm{CDM}$ from anaerobic treatment of POME. The maximum OLR achieved was $10.0 \mathrm{kgCOD} \mathrm{m}^{-3} \mathrm{day}^{-1}$ and gas productivity were 1.5 and $0.9 \mathrm{~m}^{3} \mathrm{~m}^{-3} \mathrm{day}^{-1}$, respectively for biogas and methane. By increasing the sludge recycling rate upon higher application of POME loading rate, the treatment process was stable with VFA concentration recorded below its inhibitory limit $\left(1000 \mathrm{mg} \mathrm{L}^{-1}\right)$ and the COD removal efficiency recorded was higher than $95 \%$. This indicated good treatment performance of the digester. However, the methane productivity was recorded lower at high OLR which was due to organic washout and methanogens shock loading. The total methane emission reduction for a 54 tons $\mathrm{h}^{-1}$ palm oil mill was more than 2 millions $\mathrm{m}^{3}$.

\section{ACKNOWLEDGEMENT}

The authors would like to acknowledge various support from University Putra Malaysia, FELDA Palm Industries Sdn. Bhd., Kyushu Institute of Technology, Japan Society for Promotion of Science Asian Core Program, University Teknologi MARA and Serting Hilir Palm Oil Mill.

\section{REFERENCES}

1. Yacob, S., Y. Shirai, M.A. Hassan, M. Wakisaka and S. Subash, 2006. Start-up operation of semicommercial closed anaerobic digester for palm oil mill effluent treatment. Proc. Biochem., 41: 962-964. DOI: 10.1016/J.Procbio.2005.10.021 
2. Najafpour, G.D., A.A.L. Zinatizadeh, A.R. Mohamed, M.H. Isa and H. Nasrollahzadeh, 2006. High-rate anaerobic digestion of palm oil mill effluent in an up flow anaerobic sludge-fixed film bioreactor. Proc. Biochem., 41: 370-379. DOI: 10.1016/j.procbio.2005.06.031

3. Chynoweth, D.P., J.M. Owens and R. Legrand, 2001. Renewable methane from anaerobic digestion of biomass. Renew. Energ., 22: 1-8. DOI: 10.1016/S0960-1481(00)00019-7

4. Bouallagui, H., Y. Touhami, R. Ben Cheikh and M. Hamdi, 2005. Bioreactor performance in anaerobic digestion of fruit and vegetable wastes. Proc. Biochem., DOI: 40: 989-995. DOI: 10.1016/j.procbio.2004.03.007

5. Hassan, M.A., S. Yacob, Y. Shirai and Y.T. Hung, 2004. Treatment of Palm Oil Wastewaters. In: Handbook of Industrial and Hazardous Wastes Treatment, Wang, L.K., Y. Hung, H.H. Lo and C. Yapijakis (Eds.). Marcel Dekker, New York, ISBN: 0824741145, pp: 719-736.

6. Faisal, M. and U. Hajime, 2001. Kinetic analysis of palm oil mill wastewater treatment by a modified anaerobic baffled reactor. Biochem. Eng., 9: 25-31. http://cat.inist.fr/?aModele $=$ afficheN\&cpsidt $=1414$ 6279

7. Fakhrul-Razi, A. and M.J.M.M. Noor, 1999. Treatment of palm oil mill effluent with the membrane anaerobic system. Water Sci. Technol., 39: 159-163. DOI: 10.1016/S0273-1223(99)00268-1

8. Borja, R. and C.J. Banks, 1994. Anaerobic digestion of palm oil mill effluent using an up-flow anaerobic sludge blanket reactor. Biomass Bioener., 6: 381-389. DOI: 10.1016/09619534(94)E0028-Q

9. Cail, R.G. and J.P. Barford, 1985. Mesophilic semi-continuous anaerobic digestion of palm oil mill effluent. Biomass, 7: 287-295. DOI: 10.1016/0144-4565(85)90067-8
10. Husaini, S.T. and A. Djajadiningrat, 1996. Palm oil mill effluent treatment by anaerobic baffled reactors: Recycle effects and biokinetic parameters. Water Sci. Technol., 34: 59-66. DOI: 10.1016/S0273-1223(96)00821-9

11. Greenberg, A.E., L.S. Clesceri and A.D. Eaton, 1992. Standard Methods for the Examination of Water and Wastewater. 18th Edn., American Public Health Association, Washington DC., USA., ISBN: 08-75532071, pp: 269-273, 429-436, 505-506, 537-538.

12. Crocetti, G., M. Murto and L. Björnsson, 2006. An update and optimisation of oligonucleotide probes targeting methanogenic Archaea for use in fluorescence In Situ Hybridisation (FISH). J. Microbiol. Methods, 65: 194-201.DOI: 10.1016/j.mimet.2005.07.007

13. Amann, R.I., L. Krumholz and D.A. Stahl, 1990. Fluorescent oligonucleotide probing of whole cells for determinative phylogenetic and environmental studies in microbiology. J. Bacteriol., 172: 762-770. http://jb.asm.org/cgi/content/abstract/172/2/762

14. Amann, R., 1995. In Situ Identification of MicroOrganisms by Whole Cell Hybridization with rRNATargeted Nucleic Acid Probes, 3.3.6. In: Molecular Microbial Ecology Manual. Akkermans, A.D.L., J.D. Elsas and F.J. Bruijn (Eds.). Kluwer Academic Publisher, Dordrecht, ISBN: 978-1-4020-2176-3, pp: 1-15.

15. Sakai, K., M. Mori, A. Fujii, Y. Iwami, E. Chukeatirote and Y. Shirai, 2004. Fluorescent in situ hybridization analysis of open lactic acid fermentation of kitchen refuse using rrna-targeted oligonucleotide probes. J. Biosci. Bioeng., 98: 48-56. DOI: 10.1016/s1389-1723(04)70241-8

16. Westernmann, P., K. Birgitte, T. Ahring and R.A. Mah, 1989. Threshold acetate concentrations for acetate catabolism by aceticlastic methanogenic bacteria. Applied Environ. Microbiol., 55: 514-515. http://aem.asm.org/cgi/content/abstract/55/2/514 